Article received on $30^{\text {th }}$ September 2014

Article accepted on $2^{\text {nd }}$ October 2014

UDC: 78(497.11)"1919/1941"

\author{
Roksanda Pejović* \\ Department of Musicology, \\ Faculty of Music, University of Arts, Belgrade.
}

\title{
AN ATTEMPT TO EVALUATE SERBIAN MUSIC BETWEEN THE WORLD WARS (1919-1941)
}

\begin{abstract}
When evaluating Serbian music between the two world wars, we take as our starting point compositions that are valuable in their own right, whether their creators were oriented towards tradition and moderate stylistic trends, or were adherents of the latest tendencies in music. Only compositions that defined their creators' stylistic profiles are considered. We are aware that the value judgments pronounced by older generations of musicologists may differ from the attitude that their younger colleagues have towards the same works. We also understand that the attitude towards the past changes to a degree, so that certain compositions once well received fade over time, but the most powerful and original ones lose nothing of their impact. We draw attention to the Romantic foundations and the inspiration that renowned European composers found in folk music in order that we may confirm the existence of the same phenomena in the music life of Belgrade. We also observe how Serbian composers mastered novel tendencies and how these tendencies endured, noting that they generally trailed behind analogous phenomena in literature and the fine arts (as was generally the case in Serbian cultural history).

Key words: national stylistic orientation; romantic-impressionist style; European musical standard; extreme musical tendencies; evaluation of musical creative work based on the selection of most important works.
\end{abstract}

Musicologists and musicians interested in the Serbian musical past have studied Serbian mediaeval music, Serbian music at the time of the Baroque, and

* Author contact information: roksanda.p@sbb.rs 
Serbian music of the $19^{\text {th }}$ century, devoting the greatest attention to Kornelije Stanković, Stevan Mokranjac and Josif Marinković. Serbian music between the two world wars attracted even greater interest not only in the contributions of individual composers, but also in historical surveys, analyses of performing practices, and music critics and other authors of texts on music.

We will try to present a complete picture of the way Serbian musical output was evaluated during that period, with standard European values in mind when dealing with the composers who tried to emulate the best representatives of certain stylistic periods, in order that we may rank Serbian composers.

As our point of departure, we take compositions that are valuable in their own right, whether their composers were oriented towards tradition and moderate styles or were adherents of the latest tendencies in music, taking into account only those works that helped shape the individual profiles of their creators. We are aware that the value judgments pronounced by older generations of musicologists may differ from the attitude that their younger colleagues have towards the same works. We are also aware that attitudes towards the past change, that certain widely recognized compositions begin to fade in their appeal, but the most powerful and original ones lose nothing of their impact.

We will examine how composers came to embrace and master new tendencies in Serbian music and how these tendencies endured, noting that they generally trailed behind their counterparts in literature and the fine arts (as was generally the case in Serbian cultural history). We will draw attention to the Romantic foundations and the inspiration that renowned European composers found in folk music in order that we may confirm the existence of the same phenomena in the music life of Belgrade and also in the works of other Serbian composers who were not associated with the former Yugoslav capital. We will examine diverse models that Serbian composers followed and their interests in contemporary trends, from Impressionism, to mildly modern and neoclassical music, to expressionist stylistic elements. Occasionally, we come across composers who temporarily abandoned their romantic and impressionist inclinations and embraced more contemporary styles. The tension of their works may have thus been heightened, but their fundamental stylistic characteristics remained unaffected. ${ }^{1}$

\footnotetext{
${ }^{1}$ Basic literature: S. Đurić-Klajn, Razvoj muzičke umetnosti u Srbiji [Development of Music in Serbia], Zagreb, Školska knjiga, 1962; V. Peričić, Muzički stvaraoci u Srbiji [Music Creators in Serbia], Beograd, Prosveta, 1969; M. Bergamo, Elementi ekspresionističke orijentacije u srpskoj muzici do 1945. godine [Elements of Expressionist Orientation in Serbian Music until 1945], Beograd, SANU, 1980; M. Veselinović, Stvaralačka prisutnost evropske avangarde u nas [Creative Presence of European Avant-Garde in our Midst], Beograd,
} 
Pejović, R.: An Attempt to Evaluate Serbian Music between the World Wars...

The romantic-national stylistic basis of the inter-war period provided for the essential characteristics of Serbian music between the late $19^{\text {th }}$ century and the year 1941; the romantic-impressionist basis did the same for the music from the first years of the $20^{\text {th }}$ century onward. The moderately modern form of musical thinking was more strongly manifested after 1927 and that of the avant-garde orientation after 1932.

We will discuss composers of the older generation, born in the $19^{\text {th }}$ or at the turn of the $20^{\text {th }}$ century, such as Petar Konjović (1883-1970), Miloje Milojević (1884-1946), Stevan Hristić (1885-1958), Kosta Manojlović (1890-1949), and Marko Tajčević (1900-1984), who lived in Zagreb, and also the somewhat younger composers Milenko Živković (1901-1963) and Svetomir Nastasijević (1902-1980). Parallel to these, we will consider the contributions of the Croatian composer Josip Slavenski (1896-1955), a citizen of Belgrade from 1924. We will take note of the inspiration they drew from national music and the traditions of Romanticism and Neo-Romanticism, sometimes from later tendencies, and observe modal sonorities in their works. They followed similar stylistic preoccupations of the major European representatives of the national orientation, some of whom were active in the first half of the $20^{\text {th }}$ century and whose powerful musical statements introduced new ideas into tradition. These included Igor Stravinsky (until 1923), Leoš Janáček (until 1982), Sergei Rachmaninoff (until 1943), Béla Bartók (until 1945), Manuel de Falla (until 1946), and Jean Sibelius (until 1957).

It is evident that those Serbian composers who were inspired by national music did not join the ranks of European composers with kindred interests at the moment the national orientation of music emerged, but only later, at the time of the last great representatives of this style. Some Serbian composers shaped their musical profiles under the direct influence of the greats: Konjović took Janáček as his model, whereas Slavenski and Tajčević were no strangers to Bartók's music. Nationally oriented Serbian works of music were not necessarily based on the Romantic style: Marko Tajčević started from the moderately contemporary style, while Milenko Živković blended folk melodics with an objective, antiRomantic musical language closer to the musical reality of his time.

We observe romantic and impressionist traits in early Konjović, Milojević and Hristić, formed during the lifetime of the originator of Impressionism, Claude Debussy. Contemporaneous with Serbian achievements were Debussy's Images

Fakultet muzičke umetnosti, 1983; R. Pejović, Opera i balet Narodnog pozorišta u Beogradu (1882-1941) [Opera and Ballet of the National Theater in Belgrade (1882-1941)], Beograd, FMU, 1996; R. Pejović, Muzička kritika i esejistika u Beogradu (1919-1941) [Music Critique and Essays in Belgrade (191-1941)], Beograd, FMU, 1999; R. Pejović, Koncertni život u Beogradu (1919-1941) [Concert Life in Belgrade (1919-1941)], Beograd, FMU, 2004. 
(1905), Préludes Book One (1910), and the orchestral La mer (1903-1905). Later works by Serbian composers include some of Konjović's Lyric Songs; elements of Impressionism have been noted in Milojević's Sonata for Violin and Piano (1924), Hristić's Twilight (1925), the first act of The Legend of Ohrid (1933), and in some of his songs and choral music. All these creative activities coincided with those of Debussy's followers Maurice Ravel and Albert Roussel.

Another great composer whose influence must not be overlooked was Richard Strauss. To Miloje Milojević, he became a model soon after the former had written his masterpieces Salome (1905), Electra (1909), and Ariadne auf Naxos (1912). Milojević endeavored to imbue his songs with Straussian drama and to recreate Strauss's dazzling orchestration in his symphonic poem The Death of the Jugovic Mother (1921), whereas his respect for Strauss's personality was expressed in his excellent study published in the journal $Z v u k$ in $1934 .{ }^{2}$

Romantic inspiration and neo-romanticism without any emphasis on national traits are characteristic of several composers who created their works in Belgrade from 1928 on: Petar Stojanović (1877-1957), Milenko Paunović (1889-1924), Sava Selesković (1893-1941), and Jovan Bandur (1899-1956).

Richard Wagner's melodics influenced Stojanović's and Paunović's operas, whereas impressionist elements are prominent in the oeuvres of Selesković and Bandur.

A further step towards modernity was taken by Mihailo Vukdragović (1900-1986), the Slovenian Mihovil Logar (1902-1998), who became a Serbian citizen, and Predrag Milošević (1904-1988). While studying at Paris, they were not close to avant-garde aspirations, but they abandoned Romanticism that still persisted at that time, mostly in the works of older generation composers. After 1927, their works adopted a more modern expression. Whereas Vukdragović inclined towards moderately contemporary tendencies and even made use of stylized folk idioms, Logar took a step further, reaching atonality; Milošević composed neo-classical works that were divested of subjectivity and sentimentality, but did not totally renounce national music.

Expressionist elements that did not result in abandoning the primary stylistic orientations can be noted in the works of Konjović, Milojević and Slavenski composed in Belgrade after 1918, before the youngest generation of Serbian composers returned from their studies in Prague. Milojević also had some affinities with Surrealism.

Having been exposed to Expressionism and quarter-tone music in Prague, the young Serbian composers - called "avant-garde" in musicological literature

2 "Rihard Štraus", Zvuk, 1934, 8/9, 285-322. 
- manifested such inclinations in their early works, created on their return to Belgrade after 1932. This took place thirty three years after the emergence of Expressionism in 1899 and lasted until 1939. Other interests followed, directed towards other styles.

The influence of dodecaphony and Schoenberg are noticeable in the works of Dragutin Čolić (1907-1987), Milan Ristić (1908-1982), and Vojislav Vučković (1910-1942). Čolić and Vučković also embraced athematicism and atonality, and so did Ljubica Marić (1909-2003) and Stanojlo Rajičić (1910-2000). Čolić, Ristić, Vučković and Marić also showed some interest in composing using Alois Hába's quarter-tone scale.

Along with literature and the fine arts, music also occupied a prominent place in inter-war Belgrade, as evidenced by renowned foreign musicians and ensembles that performed in the city, as well as by the Belgrade Opera, the Belgrade Philharmonic Orchestra and other musical and cultural institutions, which intensified musical life. Works by Serbian composers were also part of that life. ${ }^{3}$ In addition to the repeated performances of some operas and ballets, a number of concert pieces were also performed more than once. At the same time, certain composers became well-established by having several of their works performed. This was partly due to the resourcefulness of these composers in promoting their works among Belgrade music lovers and also to the positions in musical life held by prominent composers, conductors and music critics that enabled them to implement musical policies with authority. Intended for the Belgrade musical public, such compositions were of sufficiently high quality to arouse the interest of Belgrade intellectuals with an affinity for music. However, there were also pieces that did not adequately reflect the composer's profile and have faded into oblivion. On the other hand, works of considerable value did not always have the opportunity to be performed, while the number of performances of certain compositions was negligible, and such works could not contribute to the popularity of the composer.

A survey of the most frequently performed compositions will remind us of the attitude of our predecessors towards the music of their past and their present. Whereas audiences were only occasionally reminded of the composers of the late $19^{\text {th }}$ and early $20^{\text {th }}$ centuries (with the exception of Stevan Mokranjac and Josif Marinković), and even of some of the contemporary ones, ${ }^{4}$ the most frequently performed composers were those that are still held in high esteem, such as Petar Konjović, Miloje Milojević, Josip Slavenski and Stevan Hristić.

\footnotetext{
${ }^{3}$ R. Pejović, Opera i balet ....; Ibid..... Koncertni život u Beogradu...

${ }^{4}$ This refers to Anđelić, Bandur, Bošnjaković, Vijatović, Đorđević, Ilić, Jenko, Joksimović, Ljubica Marić, Pašćan, Selesković, Stanković, Tkalčić, Urban, Crvčanin, Čolić, Švarc, Šijački, and Štirski.
} 
Composers Stanislav Binički, Petar Krstić, Kosta Manojlović and Svetomir Nastasijević made sure that, owing to public performances, their works would not be forgotten. Neither did Milenko Paunović, Mihailo Vukdragović, Milenko Živković, Mihovil Logar or Predrag Milošević remain unknown. Among the youngest generation, only Vojislav Vučković and Stanojlo Rajičić had the privilege of being performed frequently.

The presence of compositions by Konjović, Milojević, Hristić and Slavenski in the inter-war period resulted in their popularity. Although the number of performances was not high, it greatly exceeded that of the compositions by their contemporaries. Konjović and Slavenski chiefly promoted the national orientation: Konjović with his operas The Prince of Zeta (premiered in 1929), Koštana (with its two premieres in 1931 and 1940), along with frequent performances of various instrumental and vocal excerpts from the latter, as well as with his solo songs and church music, and Slavenski particularly with his Balkanophony, Religiophony, and choral and chamber music.

Between 1919 and 1941, Milojević and Hristić remained faithful both to romantic-impressionist music and music of national orientation. Milojević endeavored to capture his audiences with solo songs, especially The Nymph, Japan, Autumn Elegy, The Song of the Wind from the Sea, and The Eagle's Song; also with several pieces of choral music, particularly the compelling The Fly and the Gnat and Foreboding; with his church and orchestral music (the symphonic poem Death of the Jugovic Mother and the suite Intimacy), and Hristić with excerpts from The Legend of Ohrid and Resurrection. ${ }^{5}$

Among the oldest generation of composers, works by Petar Stojanović and Milenko Živković enjoyed a certain degree of popularity. Stojanović's chamber music became available to the public in 1919, the symphonic poem Death of the Hero in 1926 and the symphonic suite The Sava in 1935. Živković's pieces, more often performed between 1933 and 1940 - more precisely, over thirty-five times during that interval - included his choral work A Fly on the Motor Car, excerpts from the ballet The Green Year, Symphonic Prologue, the prelude to the cantata The Birth of Spring, a classical suite for flute and orchestra, and a number of other works.

By 1927 , works by other nationally or neo-romantically oriented composers, such as Paunović, Bandur, Tajčević, Selesković, Tkalčić, Urban and others, ${ }^{6}$

5 See Appendix Pregled izvođenja kompozicija značajnih srpskih muzičkih stvaralaca (izbor) [A Survey of Performances of Compositions by Major Serbian Composers (Selection)].

${ }^{6}$ P. Konjović, songs Pod pendžeri [Under the Windows] (pefromed in 1921) and Sevdah (1927); M. Tajčević, Balkanske igre (performed in 1922, 1930, 1932); M. Milojević, songs 
Pejović, R.: An Attempt to Evaluate Serbian Music between the World Wars...

had also been performed, whereas in the short period 1927-1931, before the advent of the youngest generation of Serbian composers, the public could also hear works by neo-romanticists, such as Logar and Milošević... ${ }^{7}$

Paunović gained popularity with his Yugoslav Symphony, performed six times between 1924 and 1940, a kind of precedent in the inter-war period. Bandur was more modest, restricting himself to solo songs with piano or orchestral accompaniment. As early as 1930, Tajčević's Balkan Dances earned the acclaim of performers and listeners alike and has become part of the standard pianistic repertoire throughout the former Yugoslavia. Created in 1928, his Four Spiritual Verses was performed in Zagreb in 1929 and in Belgrade in 1930. The symphony Impressions of the Soul and the symphonic suite The Homeless by Sava Selesković are the most representative works of their creator. Logar was among the more frequently performed composers owing to his symphonic movement Vesna (The Spring Goddess), string quartets (including a lullaby and a funeral march), Toccata seria and Toccata giocosa, The Legend of Mark for bass and piano... After its Prague premiere, Milošević's Sinfonietta was repeatedly performed in Belgrade. Other pieces presented to the Belgrade audience included his Small Piano Suite and Piano Sonatina.

Milojević, a member of the oldest generation of Serbian inter-war composers, showed his interest in the most modern tendencies both before and after the return of young Serbian composers from Prague: in 1923, 1924 and 1935 in his opera-ballet The Valet's Broom (1923), after a surrealist scenario by Marko Ristić; in his Three Songs on German Verses (1924-1942), containing elements of Expressionism; in his expressionist oriented choral cycle A Feast of Illusions (1924), and his piano piece Rhythmic Grimaces (1935).

An inclination towards the most modern trends in composition is strongly felt in the works of the youngest Serbian composers. The existence of Serbian

Jesenja elegija (1922) and Japan (1923), Melanholično veče [A Melancholic Evening], for piano (1923), U vrtu [In the Garden] and Stara priča [An Ancient Tale] from the collection Cetiri komada za klavir [Four Pieces for Piano] (1926), symphonic poem Smrt majke Jugovića [Death of the Jugović Mother] (1923), Pesme iz Južne Srbije [Songs of Southern Serbia] (1928), song Buba-Mara [Ladybug] (1932); S. Paunović, Fuga i preludijum [Fugue and Prelude] (i1927); J. Slavenski, Balkanski nokturno [Balkan Nocturno] (1927); J. Bandur, Selesković, Tkalčić, Urban Himna čoveku (A Hymn to Man] for choir, narrator, flute, two clarinets, bassoon, trumpet and piano (1928) and Svatovska pesma [Wedding Song] (1932).

${ }^{7}$ M. Logar, Tango and Džez-groteska [Jazz Grotesque], Serenada [Serenade], Romansa o mirisu smrekine smole [Romance on the Fragrance of Juniper Resin] (1927), Sonata for Violin and Piano (1928), Antička igra [Antique Dance] for flute and piano (1928), Capriccio pastorale for flute and piano (1928), Second String Quartet (1928 and 1929); P. Milošević, Mala klavirska svita [Small Piano Suite] (1928), etc. 
avant-gardists in Prague was confirmed when their early works appeared, such as the Wind Quintet by Ljubica Marić (1909-2003), composed in 1931 and first performed in Amsterdam in 1933. Its ideas were similar to those of the antiromantically and objectively conceived Concertino for Quarter-tone Piano and String Sextet by Dragutin Colić (1932), first performed in Prague in 1937. Young composers conducted their own works in Belgrade: Ljubica Marić conducted Music for Orchestra (1933), performed by the Stanković Orchestra in 1934, and Milan Ristić his Sinfonietta, performed by the Radio Orchestra in 1940.

"The purest example of Serbian musical Expressionism" in all its compositional elements could only be heard in Two Songs for Soprano and Wind Trio by Vojislav Vučković, composed in 1938 and performed twice that year, in Belgrade and at the London Festival organized by the International Society for Contemporary Music. His Quarter-tone Duo was performed in December of 1935 in Belgrade, and his First Symphony (1933) was broadcast by Prague Radio in 1933. The Belgrade Philharmonic Orchestra performed it several times. These were not the only publicly performed works by Vučković: several pieces in his later oeuvre were also included. ${ }^{9}$ In addition to an evening concert he organized before departing to Prague for his studies, Stanojlo Rajičić offered to Belgrade audiences a significant number of first and repeated performances of his compositions: First Symphony in 1938 and 1939, Concert Overture in 1938, Second String Quartet in 1940, and music for the ballet Under the Earth in 1940 and 1941.

The musical and ideological foundation of the Serbian inter-war period was diverse.$^{10}$ It was formed under the auspices of two musicologists, the composers and music educators Milojević and Vučković, who were adept at words as much as music. The authors who wrote about music produced a vast number of reviews and articles on music. Some of them published collections of articles or special editions dedicated to outstanding personalities. They strived to be objective but sharp, judging Serbian contributions by European standards. Being musicians with degrees from conservatories and universities, they were able to provide an analytical evaluation of the compositions they discussed. Milojević was the greatest authority, while a considerable reputation was also enjoyed by Branko Dragutinović (1903-1971), Vojislav Vučković, Milenko Živković, Mi-

\footnotetext{
${ }^{8}$ M. Koren, op. cit, p. 154.

9 Such as Small Piano Suite performed in 1932, Symphony, performed in 1933, 1934 (I movement), 1937 and 1939, introdcutory music to the play Ali Binak performed in 1939, symphonic image Luminous Way (1940), choral song Marika moma ubava [Marika, the Beautiful Maiden] (1940), and finally First Song Garland, performed in 1944.

${ }^{10}$ R. Pejović, Muzička kritika i esejistika... [Music Critique and Essays...]
} 
Pejović, R.: An Attempt to Evaluate Serbian Music between the World Wars...

hailo Vukdragović, and Dragutin Čolić. They held diverging views concerning the path Serbian music ought to take in order to assume its proper place in the international musical world. Milojević was an advocate of musical nationalism and was the most vocal among his contemporaries; Vučković and Živković had their own visions of musical realism. There were composers who did not believe in going back to national music, that is, in composing in the spirit of folk melodics (Vučković); for them, the national style was but "a stage in the evolution of music, not its goal" (Živković), and thus "the national style has become obsolete" (Čolić). Whereas Milojević opposed "the frantic modern music" (though his reviews were sometimes more moderate), Vučković stated that Impressionism was "degenerate". To this, Živković appended the attribute "decadent", and he called contemporary Czech music "nondescript cosmopolitanism". Čolić, however, permanently championed contemporary musical creation, indicating that we are two decades behind the actual trends in the contemporary music world.

The contributions of Mokranjac and Marinković were considered exemplary, whereas the works of Joksimović, Đorđević, Binički, Krstić, and Bajić, as emphasized by Mihailo Vukdragović, put an end to the aspirations of $19^{\text {th }}$ century music. The place of honor was allotted primarily to the adherents of the late romantic-national and romantic-impressionist musical languages. A certain degree of reserve was shown regarding the followers of the moderately contemporary stream, while, as a rule, there was little understanding for the most modern, avant-garde music.

Hristić, Milojević, Konjović and Slavenski were judged as the most prominent composers of their time, even if the work of the last mentioned was not so well understood. Certain authors included Manojlović, Paunović and Nastasijević in the list. The importance of Živković, Vukdragović, Logar and Milošević was often stressed; and the value of Ljubica Marić, Čolić, Vučković, Rajičić and Ristić was also recognized.

It is not difficult to conclude that a significant number of present-day musicians, composers and musicologists, with some exceptions, uncritically accepted the inter-war evaluation of Serbian compositional achievements. The chief discrepancy was with regard to the expressionist orientation of the youngest generation of composers. We point out general or individual appraisals concerning smaller or greater contributions by our esteemed composers, whereby Konjović was preferred to Hristić and Milojević; not enough notice was taken of Kosta Manojlović's choral music, Živković's results, Milošević's contributions (generally labeled as impressionist), also of Logar's, who had by that time already composed unique, recognizable sharp-sounding pieces with freely conceived vertical sonorities. 
Our aim is to single out works that marked their time and to point out valuable compositions that were nonetheless deprived of their rightful places in the musical life of Belgrade between the two world wars. Our present-day understanding of compositions from that period is considerable, particularly as contemporary musicologists have taken part in symposia devoted to the inter-war composers and approached their works analytically. Anyhow, had there been no other publication but the book Muzički stvaraoci u Srbiji [Music Creators in Serbia] by Vlastimir Peričić, ${ }^{11}$ there would be sufficient insight into inter-war musical creations. Hardly any writers on music, except Branko Dragutinović, mentioned European standards when evaluating the compositions that were created and performed, which does not mean that they did not apply these criteria. In our selection of the most important compositions (which is subject to change), we were guided by their possible originality and their immediate impact on listeners, in the sense of the latter's ability to experience their content. We believe that, owing to their high artistic level, these compositions are worthy of being included in a group of achievements that meet European standards established by eminent music creators of worldwide reputation. We did not strictly adhere to the years that frame Serbian music between the two world wars, because even youthful works by the oldest generation, created towards the end of the $19^{\text {th }}$ century, belong to the period that blossomed between 1918 and 1941.

In the first two decades of the $20^{\text {th }}$ century, our selection focuses on nationally oriented compositions and those composed in the romantic tradition imbued with impressionist elements. These include early solo songs by Konjović, Milojević, and Hristić; Hristić's oratorio Ressurection, Konjović's female choral music with piano accompaniment, and a selection of Milojević's collection of piano pieces from 1917.

The third and fourth decades saw the most mature achievements of the already existing or new styles: Hristićs verist-impressionist opera Twilight, the first act of the ballet The Legend of Ohrid; Petar Konjović's The Prince of Zeta and Koštana, the two operas inspired by national music and characterized by the melodics of the demotic idiom; also Milojević's Sonata for Violin and Piano; and several other works. At that time - from 1924 onward, to be precise - Josip Slavenski composed his best works in Belgrade, Balkanophony and Religiopho$n y$, which possess an archaic sonority and distinctive rhythm and harmony. Belonging to the same period are the moderately contemporary, nationally oriented oeuvre of Marko Tajčević (Seven Balkan Dances and Four Spiritual Verses), the neo-classical compositions of Predrag Milošević, and expressionistically oriented works composed by Ljubica Marić and Vojislav Vučković.

${ }^{11}$ Beograd, Prosveta, 1969. 
Pejović, R.: An Attempt to Evaluate Serbian Music between the World Wars...

Observing the scenic works from the past centuries from a present-day perspective and aware of the current European attitude towards operas and ballets from the past, we assume that Konjović's operas and Hristić's Twilight and The Legend of Ohrid should undergo certain adaptations in order that modern audiences might accept them.

Milojević's Melodies and Rhythm from the Balkans and some other unpublished piano compositions extended the romantic-impressionist level of creation as far as the fifth decade of the $20^{\text {th }}$ century. ${ }^{12}$

Although thwarted by endless struggles for the liberation of the country, Serbian culture - including music - saw intensive development from the mid$19^{\text {th }}$ century onward, culminating in the internationally renowned works of Stevan Mokranjac. This predilection for folk music continued between the world wars. We have discussed composers of that period and their stylistic affinities, we have followed performances of their compositions and studied critical opinions expressed about their work by their contemporaries. Bearing in mind the present views on that period, we were forced to make such a selection that would include works by the most important composers, and to subject to assessment the performing practices of that time, since not everything that was performed at the time provided a realistic picture of the value of everything that was being composed and performed. We have expressed our disagreement with our predecessors with respect to the stylistic classification of certain compositional achievements, and we have not agreed, either, with some assessments made by a number of our contemporaries. Based on the examination of the musical events and a historical survey of the period between the world wars, we have been able to conclude that Serbian music, with its prominent compositions, ennobled by concurrent tendencies in European music, did reach European standards.

\section{Selected Works by Inter-war Music Creators}

Petar Konjović (1883-1970)

Lirika [Lyric Songs], collection of solo songs (1903-1922: Nimfa [Nymph] from 1908, Japan from 1909, Jesenja elegija [Autumn Elegy] from 1911) Three female choral music pieces with piano (1906-1916; 1917 first performance - Choir of the Zagreb Conservatory, conductor Ć. Junek; in Belgrade, 1921 - Lisinski choir from Zagreb, conductor V. Benković; and 1937: Women's Music Society from Novi Sad, conductor S. Pašćan)

Knez od Zete [The Prince of Zeta], opera (premiere 1929, Belgrade opera)

Koštana (premiere 1931; reprised 1940, Belgrade Opera)

${ }^{12}$ See Appendix Selected Works by Inter-war Music Creators. 
Miloje Milojević (1884-1946)

Pred veličanstvom prirode [In Awe of the Magnificence of Nature], collection of solo songs (1908-1920; after 1919 individual songs performed by I. Milojević, M. Agatonović-Bošković, M. Paranos, M. Jovanović, et al.)

Four Pieces for Piano (1917) - selection;

Sonata for Violin and Piano op. 36 (1924) - performed in 1924. in Prague (J. Penelski and J. Heržman), 1927 in Belgrade (M. and O. Mihailović; also Z. Baloković, M. Dimitrijević, et al.)

Muha i komarac [The Fly and the Gnat], choral music (1930) - performed in 1930 (Choir Stanković, conductor M. Vukdragović; also Women's Music Society from Novi Sad, conductor S. Pašćan, et al.)

Melodije i ritmovi sa Balkana [Melodies and Rhythms from the Balkans], collection of piano pieces (1942) - selection

Stevan Hristić (1885-1958)

Vaskrsenje [Ressurection], oratorio (1912; performed in 1912, Choir Stanković, Orchestra of the Royal Guard, conductor S. Binički)

Solo songs (from 1919) - selection; performed by J. Hristić, L. Diniko-Kalmić, J. Stefanović, I. Černa-Mijović, B. Kezer, Z. Đunđenac, A. Rostovceva, L. Popova, O. Oljdekop, J. Stamatović-Nikolić, Ž. Tomić, M. Bošković-Agatonović, N. Stajić. M. Paranos, et al.)

Suton [Twilight], opera (premieres in 1925 and 1930, Belgrade Opera)

Ohridska legenda [The Legend of Ohrid], ballet (premiere of Act I in 1933, ballet ensemble of Belgrade Opera)

Josip Slavenski (1896-1955)

Balkanofonija (1927; in 1928 performed by Belgrade Philharmonic, conductor L. Matačić; in 1929 performed by E. Kleiber in Berlin; later by Belgrade Philharmonic, conductor S. Hristić; Belgrade Philharmonic, conductor M. Vukdragović; Radio Orchestra, conductor M. Vukdragović)

Religiofonija (1934; performed in 1934, soloists, choir Obilić and Belgrade Philharmonic, conductor J. Bandur

Marko Tajčević (1900-1984)

Sedam balkanskih igara [Seven Balkan Dances], piano collection (1926; in 1927, first performed in Zagreb by S. Stančić; in Belgrade performed after 1930 by I. Noč, B. Jelača, N. Vlašić, LJ. Maržinec, M. Čop, et al.)

Četiri duhovna stiha [Four Spiritual Verses], choral music (1928; choir Lisinski, conductor M. Saks, first performed in Zagreb in 1929, then by the same choir in Belgrade in 1930) 
Pejović, R.: An Attempt to Evaluate Serbian Music between the World Wars...

Predrag Milošević (1904-1988)

Sinfonietta (1930; in 1931, performed in Prague, Czech Philharmonic, conductor K. B. Jirak, then, in 1932, in Belgrade, Belgrade Philharmonic, conductor S. Hristić)

Ljubica Marić (1909-2003)

Wind Quintet (1931; performed by Prague Wind Quintet in Belgrade in 1931 and Prague in 1932, and in 1933 by The Hague Wind Quintet in Amsterdam, at the Festival of the International Society for New Music)

Vojislav Vučković (1910-1932)

Two songs for soprano, oboe, clarinet and bassoon (1938; performed in 1938 by Z. Đunđenac, R. Langer, V. Živojinović and G. Linger in Belgrade; the same year in London, performance organized by the International Society for New Music, and in Belgrade) 